\title{
A pandemia da COVID-19 e os conflitos entre ciência e opinião: desafios para o conhecimento formal
}

\author{
The COVID-19 pandemic and the conflicts between science and \\ opinion: challenges for formal knowledge
}

La pandemia de COVID-19 y los conflictos entre la ciencia y la opinión:
desafíos para el conocimiento formal

Recebido em 21-07-2020

Modificado em 08-09-2020

Aceito para publicação em 01-11-2020

\section{Paulo Sérgio Raposo da Silva}

ORCID: 0000-0003-3558-3448

Graduado em Ciências da Religião pela Universidade do Estado do Rio Grande do Norte, mestrando em Educação pela UFRN - Universidade Federal do Rio Grande do Norte, Brasil e integrante do Grupo de Estudos da Complexidade (GRECOM). E-mail: pauloraposo10@gmail.com

\section{Resumo}

Este artigo, a partir de uma análise qualitativa de natureza exploratória, discute as diferenças entre os saberes científicos, construídos e consolidados por meio de coletividades e consensos rigorosos, e a opinião como mera expressão de saberes individuais cuja validade, na maioria das vezes, não se submete à análise e à crítica ao ponto de produzir ações descuidadas que põem em risco as relações sociais, tendo como mote as consequências da pandemia provocada pelo novo coronavírus. Para tanto, fundamentalmente, o estudo embasa-se nas contribuições teóricas do Pensamento Complexo e propõe mudanças no método científico clássico inflexível. Ademais, demonstra o lugar ocupado pela universidade nesse debate, além de definir cada um daqueles saberes e apresentar os desafios que a pandemia escarçou.

Palavras-chave: Pandemia; Universidade; Ciência; Opinião. 


\section{Introdução}

Este trabalho foi construído a partir de uma análise qualitativa de cunho exploratório e busca definir as características dos saberes científicos tradicionais e da opinião para identificar as diferenças que existem entre essas maneiras de expressar o pensamento, de sorte a ser possível distingui-las sem, no entanto, acirrar rivalidades que são conhecidas, seja por causa do próprio modo com que a ciência moderna cartesiana aborda o senso comum ou como este lida e rejeita aquela, quando procura se afirmar e, sobretudo, quando, em momentos de crises, como o atual, provocados pela pandemia da COVID-19 ${ }^{1}$, aquele senso mostra que ainda possui ampla capacidade de convencimento e mobilização.

Sabe-se que existem diferentes abordagens epistemológicas e metodológicas a que as ciências recorrem para comunicar seus achados. Algumas conseguem feitos extraordinários, enquanto outras, ao fecharem-se em si e falar somente para seus pares, perdem em alcance e restringem-se ao lugar-comum dos seus laboratórios. Nessa perspectiva é que este estudo toma como paradigma de análise o Pensamento Complexo, que perpassa a obra de Edgar Morin e critica a parcela da comunidade científica que reifica linguagens, métodos, conceitos e formas de inserção no debate público sem a devida adaptação às condições socioculturais que pedem a intervenção do pensamento.

Para este artigo, a crítica torna-se necessária porque, embora existam experiências do fazer científico que se destaquem por sua natureza não-normativa, ainda há práticas hegemônicas que têm dificuldades de se relacionar com o grande público e comunicar suas teses e proposições. Do contrário, as redes de (des)informações não conquistariam mentes e consciências com tamanha facilidade como a que se vê no contexto atual, e, para responder a esse dado da realidade e para todos que fazem ciência, não há outras práticas a criticar que não sejam as suas, sob pena de transferir o ônus sem a devida autocrítica e progresso dos conhecimentos.

A pandemia provocada pelo novo coronavírus, na virada do ano de 2019 para o ano de 2020, expôs de modo absolutamente claro as incoerências, debilidades e fragilidades do sistema financeiro e das relações sociais construídas e normatizadas ao longo do tempo pelos povos e nações. Atônitos com todas as notícias que surgiram e a mortandade em massa promovida pela doença, as pessoas e o mundo, do oriente ao ocidente, pararam e

\footnotetext{
${ }^{1}$ Acrônimo cunhado pela Organização Mundial da Saúde (OMS), derivado da designação em inglês Corona Virus Disease (Doença do Coronavírus), seguida do número 19 que faz referência a 2019, ano em que os primeiros casos surgiram e foram conhecidos pelo mundo.
} 
obrigatoriamente tiveram de adotar medidas emergenciais que desestabilizaram velozmente os projetos de governo até então em desenvolvimento, os planos políticos de líderes, a política e as relações internacionais.

As particularidades da COVID-19 e a escassez de dados acerca de como a peste atua ou poderia atuar logo que surgiu tomaram a todos de sobressalto, de modo que o aparato tecnocientífico à disposição não conseguiu acompanhar o ritmo avassalador do seu progresso e evitar números terrivelmente assustadores de mortes, apesar do empenho e da corrida contra o tempo feita por países conscientes do problema e comunidades científicas gabaritadas. Essa escassez produziu um vácuo que, por sua vez, serviu muito bem a todos que fazem da internet e seus infindáveis recursos ferramentas pelas quais alcançar seus interesses, reproduzir suas ignorâncias e multiplicar desinformação, consciente e inconscientemente.

Acontece que a pandemia não revelou e escarçou somente problemas de ordem meramente econômicas. A crise lançou luz sobre os dilemas humanos, dos mais concretos aos mais abstratos, da simples sobrevivência até a aspectos que apelam às espiritualidades, assim como pôs em questão os modos por meio dos quais as pessoas tiram suas conclusões e a partir dessa ação agem na sociedade. Essa situação, dada a gravidade sanitária global imposta por um vírus tão complexo, deve provocar cientistas não apenas no que se refere à produção de vacinas, remédios e tratamentos, mas também mobilizar os círculos de conhecimento para que, ao lidar com os desdobramentos da crise sanitária, tenham algo a dizer e contribuir acerca do comportamento humano frente a momentos extremos.

É possível dizer, portanto, que a geração do presente está experimentando um desafio que perpassa ordens científicas, econômicas, políticas, sociais, culturais, afetivas e relacionais. Essa natureza do desafio, curiosamente, coincide com os aspectos da realidade humana que são físicos, biológicos, psicológicos, sociais, mitológicos, econômicos, sociológicos e históricos (Morin, 2012), tratados indevidamente de maneira separada e compartimentada. Nesse sentido, mais do que uma coincidência, a crise global constitui-se como uma interpelação às maneiras tradicionais, assentadas sobre modelo moderno clássico de interpretar o homem e seu lugar na natureza, justamente por mover de uma única vez, todas as dimensões da identidade do ser humano. Qualquer um dos aspectos mencionados demanda análises acuradas e rigorosas que se ocupem em não excluir, fragmentar, marginalizar ou descartar aspectos que fujam do espectro disciplinar de cada especialista.

A partir dessa constatação, este trabalho, como exercício de reflexão sociológicocultural que impulsione outros e novos debates, propõe-se a discutir a relação entre conhecimento científico e opinião, informação e desinformação, mentira e verdade sobre os 
dias sombrios e marcados pela incerteza provocados pela pandemia. Por um lado, o intuito consiste em reafirmar o papel das instituições produtoras de conhecimento sério e apresentar alguns de seus desafios na contemporaneidade. Por outro lado, por conseguinte, busca-se caracterizar o senso comum a partir de outro ponto de vista que, em vez de simplesmente acusar suas debilidades, as compreende a fim de que, em compreendendo, as ciências tomem consciência de que suas narrativas sobre a realidade são apenas algumas de tantas que estão disponíveis e disputam lugar.

\section{Conhecimento científico e a opinião: opostos que disputam espaço}

A pandemia decorrente do novo coronavírus não incidiu apenas sobre as relações interpessoais e os vínculos afetivos: explicitou de maneira significativa as fragilidades das ferramentas modernas por meio das quais as pessoas conhecem, assimilam e aderem a informações na constituição das suas opiniões sobre determinados fatos. Distantes uns dos outros e angustiados com as incertezas dos dias, os sujeitos passaram a consumir notícias, a se comunicar e estar conectados ainda mais, seja em busca de esclarecimento ou para manter certo tipo de verossimilhança com a normalidade da vida de antes. Ao estabelecerem esse tipo de relação, tornaram-se muito mais suscetíveis ao erro.

Se no que diz respeito à possibilidade de ter contato com múltiplas fontes - o que certamente asseguraria a posse de um amplo repertório de recursos para chegar a alguma conclusão factível -, a conexão imediata e os disparos em massa vindos de múltiplos remetentes podem ser considerados como um avanço tecnológico importante. $\mathrm{O}$ dado negativo e inevitável é que, exatamente por ser como são, os recursos digitais passaram a ameaçar a conscientização crítica das pessoas ao permitir a livre circulação de informações que não condizem com a verdade.

Uma vez que se configura como um espaço de amplas liberdades e, ao mesmo tempo, controle político (Loveluck, 2018), a Internet torna-se um meio de comunicação ambíguo por excelência, tanto por sua natureza quanto pelos conteúdos e agentes que ali se expressam e veiculam suas ideias e projetos de poder. A ambivalência é tão significativa que o debate sobre se o modus operandi das redes é mais nocivo ou benéfico à convivência democrática e à construção de saberes possui um conjunto de variáveis e controvérsias que suscita debates aparentemente intermináveis; mas um aspecto pode ser tomado como certo: positiva e negativamente, a internet veio para "submeter o aparelho à vontade humana, e não o 
contrário" (Loveluck, 2018:123), de sorte a se constituir um "artifício humano que rege a vida em sociedade" (Loveluck, 2018:164).

Embora seja conhecida como "terra sem lei", a Rede Mundial de Computadores possui, sim, regras e controles. Entretanto, aquelas e estes são difusos, por vezes, desconhecidos, de modo que o uso pode ser pervertido e os interesses escusos daqueles que fazem seus jogos políticos a partir das fragilidades da virtualização das relações são alcançados sem muitas dificuldades e passam a definir comportamentos, ou seja, éticas (Loveluck, 2018) que, por consequência, deixarão suas marcas e mostrarão seus males no convívio social, justamente o mais perturbado por aquela que tem sido considerada a mais terrível crise humanitária da história.

No contexto de confinamento imposto pela COVID-19, essas características se expandem e ficam clarividentes. Por meio de um simples smartphone, informações, opiniões, vontades e ideários se multiplicam avassaladoramente. Tomadas pelo pânico, mesmo que bem intencionadas, as pessoas recebem e repassam informações sem a devida preocupação de saber suas origens e os interesses que estão por trás da veiculação daqueles dados, mesmo se estes refiram-se a questões de vida morte, porque prevalece a ideia das redes como artifício de interação, mas também de ingerência sobre a realidade contemporânea. Vive-se na escassez.

Quando a falta não diz respeito a dados e informações por parte da comunidade científica, refere-se à falta de condições básicas de sobrevivência, tais como comida para todos, água potável, saneamento básico e sistemas de saúde adequados para o atendimento dos doentes.

Aquela escassez produziu um vácuo que, por sua vez, serviu muito bem a todos que fazem da Internet e seus infindáveis recursos ferramentas pelas quais alcançar seus interesses, reproduzir suas ignorâncias e multiplicar desinformação, consciente e inconscientemente, naquilo que o (Žižek, 2020) denominou como sendo um "deserto do viral”, cujas características são tão ambivalentes quanto as condições às quais todos foram submetidos. Justamente por faltarem recursos e abundar desorientação, produto do excesso de informações em circulação é que

[...] a atual propagação da epidemia do coronavírus também desencadeou um enorme surto de vírus ideológicos que se encontravam em estado dormente em nossas sociedades: fake News, teorias da conspiração paranoicas, explosões de racismo... A necessidade concreta e bem fundamentada de implementar quarentenas reverberou nas pressões ideológicas de erguer fronteiras claras e submeter a condições de isolamento "inimigos" que representariam uma ameaça a nossa identidade (Žižek, 2020:41). 
O susto, o pavor, a angústia, o medo de ser vítima de um inimigo invisível e a vulnerabilidade psíquica e pessoal dos indivíduos nesse momento os predispõem a aderir a qualquer solução para seu mal-estar, posto que "precisam de um além, mas estendem os braços, primeiro, para o que estiver mais perto. Isso lhes dá a satisfação de precisam, mas ao mesmo tempo as limita e escraviza" (Becker, 2015:209). Por causa disso é que a comunicação virtual tem determinada vantagem nas discussões acerca da COVID-19 e sobre quais medidas pessoais adotar, afinal, "toma não apenas a forma espectral, mas também viral. Ela é contagiante na medida em que ela ocorre imediatamente em planos emocionais ou afetivos" (Han, 2018:98).

Porém, deve-se destacar o seguinte: a partir de determinados pontos, "a informação não é mais informativa, mas sim deformadora, e a comunicação não é mais comunicativa, mas sim cumulativa" (Han, 2018:106), o que, por definição, multiplicam os perigos e não necessariamente resolve os mal-estares; pelo contrário, os agrava. Mesmo assim, o agir por conta própria a partir daquilo que foi informado pelas vias digitais e sequer foi checado devidamente seguem sendo condutas comuns e o consumo inadvertido de conteúdos de fontes extraoficiais produz reações e posicionamentos exóticos, até mesmo suicidário.

Os exemplos são vários e estendem-se desde o desrespeito às normas de segurança sanitária, passando pela negação e relativização da doença até ao uso desregulado, potencialmente genocida e insensato de medicamentos apresentados como meios de salvação para uma peste acerca da qual a comunidade científica ainda não possui respostas definitivas, já que o aparecimento da COVID-19 e seus aspectos inéditos assustou a todos ao ponto de opiniões isoladas pretenderem concorrer com os conhecimentos científicos prejudicando medidas de segurança essenciais, políticas públicas e a legitimidade do consolidado e consideravelmente seguro método científico.

No segundo volume da coleção Pensar bem nos faz bem, escrita por Mario Sérgio Cortella (2015), no capítulo intitulado Opinião, o filósofo faz distinções curtas - no entanto, contundentes e compreensíveis a todos quantos não estão habituados à discussão em pauta entre o que significa opinião e conhecimento científico. Ao fazer essa distinção e mesmo considerando que a opinião tem seu lugar na sociedade, embora seja produto da frágil achologia, Cortella (2015) assevera que essa maneira de olhar o mundo, diferentemente dos conhecimentos produzidos pela academia, não é rigorosamente fundamentada e, portanto, absolutamente confiável. 
Justamente por operar de outra forma, a academia e o consenso científico devem ter a prioridade na tomada de decisões no que diz respeito ao destino de vidas humanas. Entretanto, precisam preocupar-se em estabelecer vínculos ainda mais firmes com a população para que esta acredite naqueles de maneira consistente e tenha na institucionalidade universitária um baluarte de verdades, visto que "a confiança é um ato de fé, que se torna obsoleto em vistas das informações facilmente disponíveis" (Han, 2018:121). Como defende Cortella (2015:61), "no mundo acadêmico não basta a achologia", porque ciência, ao contrário da mera opinião fortemente arraigada na individualidade ensimesmada, constrói-se "sobre uma opinião que pode ser compartilhada, discutida, comprovada e validada" (Cortella, 2015:61).

Esse processo consideravelmente democrático, longo e feito a muitas mãos é responsável por conferir ao método a segurança de que as pessoas precisam em momentos de instabilidade como o produzido pela pandemia, porque seus resultados são baseados em um árduo trabalho e aceita outras contribuições, de sorte que essa operacionalidade das ciências contém na sua própria execução os elementos que sofisticam seus conteúdos. Isso é o que deve fazer sentido e estar claro para todos, diariamente, nas demandas urgentes, no sofrimento de povos e nações. Então, a questão que se coloca é esta: o fazer e os saberes científicos são absolutamente conscientes dessa necessidade?

O método científico não é perfeito, e isso será discutido na próxima seção, todavia foi responsável por legar à humanidade grandes conquistas e livrá-la de ou mitigar outras tragédias no decorrer da história quando se posicionou corretamente, pois "o jogo da ciência não é o da posse e do alagamento da verdade, mas aquele em que o combate pela verdade se confunde com a luta contra o erro" (Morin, 2018:23), normalmente oriundo da mentira, do uso indevido de ferramentas, de tecnologias e das inteligências fragilidades, desinformadas ou deseducadas.

Como opinião e ciência são modos de pensar que geram atitudes, há, no mínimo, duas éticas que concorrem entre si, ou seja, modos de vida, de existência que disputam espaço na convivência social. Esses modos, por conseguinte, determinam os destinos de países, estados, cidades e comunidades. Sendo assim, a autocrítica dessas duas maneiras de pensar torna-se um imperativo para quem, como os cientistas, pode afastar e olhar à distância para o objeto. Afinal, acerca da convivência social e democrática, precisamos de um "pensamento prudente para uma vida decente" (Santos, 2018a), vocacionado à democratização dos capitais simbólicos por ele produzidos.

Há, pois, que se discutir os desdobramentos dessa problemática, isto é, discutir como lidar com o senso comum, com a profusão de informações e assédios comunicativo- 
ideológicos que estão a um clique, para, assim, procurar saber a maneira de se comportar mais apropriada do conhecimento formal produzido pela academia, visto que as duas formas de interpretação coexistem e, se insistirem em disputar espaço, cada um se autoafirmará à sua maneira.

O progresso dos saberes restará aquartelado em ambientes formados por parceiros de pesquisa que, no mais das vezes, apoiam seus métodos ou, no outro extremo, em rodas conversas informais que multiplicam opiniões sem a devida responsabilidade pelas consequências. Levando em consideração esses pontos, reaproximar o pensamento formal dos saberes populares cooptados pelas informações difundidas pelas redes sociais configura-se um dos mais importantes exercícios intelectuais dos tempos modernos.

Para isso, os saberes científicos devem reconhecer suas limitações e debilidades na busca de desenvolver, como uma questão central, aquilo que o Edgar Morin (2011) chama de "conhecimento pertinente", conhecimento que, por tratar do global e do contextual, daquilo que é da ordem do abstrato, mas também daquilo que é experienciado dia a dia por cada indivíduo, aproxima-se de vivências cotidianas e pode influenciá-las. Dessa maneira, os espaços que eram ocupados apenas por redes relativamente indomáveis começarão a ser preenchidos também por saberes sérios e responsáveis.

Nesses termos, a hiperespecialização produzida pela carreira acadêmica, distante das realidades que escapam dos seus laboratórios, "impede tanto a percepção do global, quanto do essencial. Impede, até mesmo, tratar corretamente os problemas particulares que só podem ser propostos e pensados em seu contexto" (Morin, 2011:38). Levada às últimas consequências, essa maneira de equacionar o problema lança muito mais desafios às instituições formadoras, sobretudo a universidade, do que ao próprio senso comum autossuficiente e recorrentemente irrefletido.

Isabelle Stengers problematiza ainda mais essa questão ao defender, dentre outros pontos fundamentais, que o método científico moderno "ao mudar de meio, ao não se dirigir mais a colegas, ao participar da invenção de inovações irredutivelmente técnicas e sociais, devem igualmente mudar de estilo ético-estético-etológico" (Stengers, 2002:155). Dito de outra maneira, o que se propõe às ciências é que, ao tentarem se inserir no debate público, adaptem suas abordagens, suas linguagens e sua imagem a fim de atender os que estão fora do seu circuito e mesmo assim precisam ser beneficiados por seus achados, tendo em vista que "o capital cognitivo acumulado pertence a todos os sapiens-demens do planeta, mesmo que a ciência, por vezes, esqueça disso" (Almeida; Knobbe, 2003:25). 


\section{A universidade e a produção de melhores conhecimentos}

Por que, depois de tantos avanços científicos e da revolução iluminista do pensamento ocidental que antecederam o século XXI, saberes que não detêm fundamentação consistente e não se expõem à experimentação ainda concorrem e rivalizam com os conhecimentos formais elaborados pela universidade e centros de excelência? Por que, em larga medida, o senso comum, facilmente atraído e convencido pelas informações que circulam nas redes, ainda prevalece nos dias de hoje?

De modo geral, a resposta tem uma dupla origem: uma antropológica e outra institucional, ou seja, uma que diz respeito ao que são e como atuam os homens, que "tendem a ficar enredados na conveniência dos paramentos que usam e dos quais precisam" (Becker, 2015:325); e a outra origem aponta para a qualidade dos ambientes acadêmicos, cujas produções podem ser absoluta e socialmente essenciais, mas se por falta de diálogo apropriado e abertura ao que e àqueles que estão fora limitar-se a seus grupos, transformarão o essencial em privilégio de poucos, o que é no mínimo questionável.

Ora, mesmo com o passar do tempo e avanços significativamente democráticos em seu modo de atuar, "a universidade - lugar onde todas as coisas se transformam em objetos de conhecimento - não consegue colocar-se como objeto de conhecimento e inventar os procedimentos para a pesquisa de si mesma" (Chauí, 2001:125). Ao se deter à burocratização das suas pesquisas e, em nome do rigor, enrijecer seus métodos, a academia supervalorizou a objetividade e legou aos saberes comuns ou da tradição espaços marginais. Em contrapartida, atingidos por realidades extremas como a da pandemia da COVID-19, os sujeitos, a partir do que têm à mão, reivindicam para si seus lugares de fala.

Aqueles que manipulam as redes e usam das liberdades ali viabilizadas usam desse fato para usar as plataformas virtuais como artifícios para manipular consciências, corpos e emoções. Os que são vítimas desse desserviço e dessa desonestidade intelectual replicam inconscientemente os conteúdos e de vítimas passam a fazer parte do problema. Esse dado deve ser uma questão central para estudiosos e todos que se preocupam com o bem-estar social, de modo que pessoas não precisem morrer porque só tiveram acesso àquilo que a internet, o senso prático e os achismos os ofereceram.

Uma autocrítica radical da institucionalidade universitária que gere um vocabulário mais democrático e aberturas dos seus espaços e reconheça o valor da multi/trans/ interdisciplinaridade contribuirá para a construção da cidadania, do senso de pertencimento e da consciência de comunidade. Essa autocrítica significa fazer com que a universidade não 
espere apenas que o povo vá a ela, mas ela irá ao povo e em contato com as demandas locais, com as experiências de cada sujeito, poderá reelaborar-se partindo também das sabedorias extramuros.

Trata-se de (re)pensar, (re)fazer e entregar a todos uma universidade que faça frente institucional, epistemológica, metodológica e culturalmente ao estado de coisas que temos e que se agrava, tendo ao mesmo tempo de lidar com sua própria natureza, seus desafios e controvérsias oriundos do lugar mesmo que a instituição ocupa socialmente e da sua tarefa enquanto produtora de conhecimentos:

\begin{abstract}
Daí a paradoxal dupla função da Universidade: adaptar-se à modernidade científica e integrá-la; responder às necessidades fundamentais de formação, mas também, e sobretudo, fornecer um ensino metaprofissional, metatécnico, isto é, uma cultura. A Universidade deve adaptar-se à sociedade ou a sociedade é que deve adaptar-se à Universidade? Há complementaridade e antagonismo entre as duas missões: adaptar-se à sociedade e adaptar a sociedade à Universidade; uma remete à outra em um círculo que deve ser produtivo. Não se trata apenas de modernizar a cultura: trata-se também de "culturalizar" a modernidade. Aqui, reencontramos a missão transecular, em que a Universidade convoca a sociedade a adotar sua mensagem e suas normas: ela inocula na sociedade uma cultura que não foi feita para as formas provisórias ou efêmeras do hic et nunc, mas para ajudar os cidadãos a viverem seu destino hic et nunc, ela defende, ilustra e promove, no mundo social e político, valores intrínsecos à cultura universitária - a autonomia da consciência, a problematização (com a consequência de que a pesquisa deve ser sempre aberta e plural), o primado da verdade sobre a utilidade, a ética do conhecimento (Morin, 2018b:82, grifos do autor).
\end{abstract}

A partir do que discute Boaventura de Sousa Santos (2018b), cumpre destacar o seguinte: deixado a si mesmo, o senso comum tende a ser pragmático, retórico, metafórico, superficial, transparente, evidente, indisciplinar, imetódico ${ }^{2}$, mistificado e mistificador. Nem por isso esse modo de descrever e lidar com os dados da realidade deixa de fecundar os imaginários, uma vez que é, por causa de um conjunto de variáveis, a única ferramenta de que muitos dispõem para atribuir significado a tudo que veem ao seu redor ou precisam vivenciar. Dada sua importância na constituição das posições de vários indivíduos, o senso comum deve voltar a mover as pesquisas e a reflexão, não como objeto para uma análise que procura desqualificá-lo, mas que o integra a fim de depurá-lo.

Traduzido pelo conhecimento científico e não marginalizado, o senso comum pode ser agente proporcionador de uma nova racionalidade, uma racionalidade composta de várias outras racionalidades que não precisam concorrer entre si, já que podem compor uma nova maneira de pensar e abordar os objetos sem, necessariamente, anular seus pressupostos;

\footnotetext{
${ }^{2}$ Neologismo criado por Boaventura dos Santos para defender um tipo de fazer científico mais flexível.
} 
apenas flexibilizá-los, torná-los mais próximos daquilo que é vivido de fato por quem está fora dos centros de produção de conhecimentos.

Trata-se, pois, de reelaborar a ética científica para que os leigos não sejam tratados como ignaros e os pesquisadores cheguem um pouco mais próximo da experiência humana local e global, "pela vivência, pela inserção, pela vida comum (e não por questionários), pelo desejo de ir em direção aos seres e dar-lhes a palavra" (Morin, 2013:176), sabendo que esses trazem consigo um saber que possui seu valor.

Em outra de suas obras, Boaventura de Sousa Santos (2011) defende que essa tarefa a que a academia deve se prestar, em busca da legitimação radical de si mesma tem uma dupla frente de trabalho: "pesquisa-ação" e "ecologia dos saberes" que, em suma, podem ser caracterizadas pela "produção de conhecimento científico ligada à satisfação de necessidades dos grupos sociais que não têm poder para pôr o conhecimento técnico e especializado a seu serviço pela via mercantil” (Santos, 2011:75).

\begin{abstract}
A pesquisa-ação e a ecologia de saberes são áreas de legitimação da universidade [...]. Consiste na definição e execução participativa de projetos de pesquisa, envolvendo as comunidades e organizações sociais populares a braços com problemas cuja solução pode beneficiar dos resultados da pesquisa. Os interesses sociais são articulados com os interesses científicos dos pesquisadores. A ecologia dos saberes é, por assim dizer, uma forma de ao contrário, de fora da universidade para dentro da universidade. Consiste na promoção de diálogos entre o saber científico ou humanístico, que a universidade produz, e saberes leigos, populares, tradicionais, urbanos, camponeses, provindos de culturas não ocidentais (Santos, 2011:74-76).
\end{abstract}

Cumpre encarar uma reforma e, em última instância, uma revolução do pensamento para a compreensão do presente e a produção de futuros melhores do que momentos trágicos sugerem. Na fórmula de Montaigne, aplicada pelo Edgar Morin, "mais vale uma cabeça bemfeita do que uma cabeça cheia" (Morin, 2018b). Para o autor, mais vale um pensamento que se movimenta e sabe estabelecer conexões do que aquele que se fecha em seus pressupostos e não constrói nada de significativamente novo, ou seja, as disciplinas precisam interagir entre si e dialogar para que cada contribua com seu arcabouço teórico e práticas:

[...] Interdisciplinaridade pode significar também troca e cooperação, o que faz com que a interdisciplinaridade possa vir a ser alguma coisa orgânica. A multidisciplinaridade constitui uma associação de disciplinas, por conta de um projeto ou de um objeto que lhes sejam comuns; as disciplinas ora são convocadas como técnicos especializados para resolver tal ou qual problema; ora, ao contrário, estão em completa interação para conceber esse objeto e esse projeto. [...] Devemos 'ecologizar' as disciplinas, isto é, levar em conta tudo que lhes é contextual, inclusive as condições culturais e sociais, ou seja, ver em que meio elas nascem, levantam problemas, ficam esclerosadas e transformam-se. [...] Não se pode demolir o que as disciplinas criaram; não se pode romper todo o fechamento: há o problema 
da disciplina, o problema da ciência, bem como o problema da vida; é preciso que uma disciplina seja, ao mesmo tempo, aberta e fechada (Morin, 2018b:115).

Há, então, que se relacionar com o mundo a partir de uma mudança paradigmática da racionalidade que deve ser mais plural, afinal de contas a hiperespecialização e a parcialização dos conhecimentos em disciplinas mutilam os saberes e produzem preconceitos, estigmas e intolerâncias, ao ponto de formar um "especialista ignorante" (Santos, 2018b), pesquisador que só compreende os acontecimentos quando esses cabem nas fronteiras estabelecidas pelas áreas do conhecimento nas quais se qualificaram. Por ignorar os saberes das pessoas comuns, esse especialista ignorante, movido pelos pressupostos que fundamentaram sua formação, faz dos homens e mulheres comuns uma espécie de "ignorante generalizado" (Santos, 2018b), como se não houvesse determinados níveis de sabedoria nessas pessoas.

Mesmo escanteada ou desqualificada, a sabedoria popular persiste e mostra suas feições, seja na adesão a práticas infundadas, seja na recusa obstinada de orientação, cuidados e precauções. Acolhida pelos saberes científicos com o devido respeito, até poderá ter relutâncias ocasionais; no entanto, ver-se-á reconhecida e valorizada. Fornecer esse estatuto aos saberes do povo é o que faz com que esse saber seja influenciado pelos saberes formais, de tal sorte que os campos de atuação da mentira minguem em ampla escala.

Afastado do centro dos debates ou caricaturado pelas racionalidades modernas iluministas herméticas, o senso comum sai da cena dos ambientes acadêmicos onde ele poderia ser devidamente acolhido e desenvolvido. Contudo, não desaparece: reivindica para si seu lugar nas redes sociais relativamente incontroláveis, nas rodas de conversa informais, nas relações familiares etc. Quando reaparece, o senso comum reclama vez e voz, e ressurge no debate público, enquanto os sistemas de conhecimento que o desprezaram capengam por não terem considerado que "a ciência se desenvolve, não só a despeito do que ela tem de não científico, mas graças a que ela tem de não-científico" (Morin, 2018a:186).

Inevitavelmente, há no horizonte o compromisso por parte das universidades e centros de produção de conhecimento de rever suas epistemologias e metodologias em busca da necessária autocrítica àqueles saberes que se encaixam no perfil criticado pelo Pensamento Complexo e por este artigo, a fim de encontrar caminhos para o diálogo aberto e para a maior eficácia no alcance de suas pesquisas. As ciências que se desenvolvem a partir da flexibilidade que as experiências da vida humana exigem devem influenciar as outras que se petrificaram e optaram por manterem-se logicamente irrepreensíveis a partir do ponto de vista 
da lealdade à teoria que escolheram como filtro a partir do qual interpretar todas as vivências, mas que são incapazes de inovar (Stengers, 2002) e refletir todas as realidades.

\begin{abstract}
O método da complexidade pede para pensarmos nos conceitos, sem nunca dá-los por concluídos, para quebrarmos as esferas fechadas, para restabelecermos as articulações entre o que foi separado, para tentarmos compreender a multidimensionalidade, para pensarmos na singularidade com a localidade, com a temporalidade, para nunca esquecermos as totalidades integradoras (Morin, 2018a:192).
\end{abstract}

A complexidade não busca anular as bases fundamentais das disciplinas, responsáveis inclusive por defini-las como tais, e sim a integração entre elas, cuja implementação requer uma "transformação multidimensional" do que se entende por ciência (Morin, 2015). Essa unidade "é evidentemente impossível e incompreensível no quadro atual onde miríades de dados se acumulam e nos alvéolos disciplinares cada vez mais estreitos e fechados" (Morin, 2015: 50). Torna-se possível, entretanto, se o pensamento estiver disposto à elaboração de teorias que operem a partir do princípio da auto-eco-organização ${ }^{3}$, isto é, teorias que operem em colaboração mútua porque entendem-se como resultado da interação com o meio em que sugiram e por meio do qual regulam-se. Dito de outra maneira, a integração que se busca "respeita a física, a biologia, a antropologia, mas quebra o fisicismo, o biologismo, o antropologismo" (Morin, 2015:50).

Em tempos de fake News, os entraves impostos por tendências negacionistas tensionam as relações, degeneram o debate e constroem tipos de militâncias exóticas que podem levar seus agentes até as vias de fato como, por exemplo, reagir violentamente à refutação de quem pensa diferente mesmo que esse pensar esteja baseado em evidências e tenha sido construído a partir do consenso de comunidades científicas da área em que a discussão se insere ou a partir da qual emerge. Retorna-se, assim, a um aspecto moral circular: saber devidamente o que precisa ser feito redunda em fazer a coisa certa. Subjaz nesse debate a ideia de cidadania e como exercê-la.

Conforme defende Edgar Morin (2018b), em uma democracia, um cidadão é definido por sua solidariedade, reponsabilidade e relação a sua pátria. Ao consumir informações falsas e difundir dados inauditos, como já foi apontado, as pessoas elaboram suas opiniões e essas são reflexos da individualidade de cada um. Assim, ter uma opinião do tipo "cada um com a sua e não se discute" significa decidir atuar por conta própria sem o senso de coletividade, portanto, constitui-se o oposto da cidadania, segundo a definição moriniana.

\footnotetext{
${ }^{3}$ Conceito fundamental no Pensamento Complexo, segundo o qual a ciência não se produz isolada, como que em um quarto fechado em quatro paredes, mas se auto-eco-produz, "já que sua ecologia é a cultura, é a sociedade, é o mundo" (Morin, 2018a:61).
} 
Ora, se o sujeito resolve tomar suas decisões e fazer o que lhe vem à cabeça contra as mais sensatas recomendações no contexto da COVID-19, pior do que exigir seu direito à fala e opinião, ele está operando contra a democracia, contra relações interpessoais saudáveis e pondo em apuros a si e todos que consigo formam a sociedade. Sua opinião deixou de ser uma sabedoria e passou a ser um projétil.

Acerca dessa transformação, nem sempre percebida por pesquisadores que de fato respeitam as sabedorias populares e as consideram, as instituições formadoras de profissionais e especialistas devem se posicionar. Percebe-se, assim, uma relação ambígua, já que, ao passo que uma racionalidade precisa contemplar outras racionalidades para ampliar sua atuação, também precisa ficar atenta às perversões que do senso comum podem surgir.

É tarefa universitária responder a esse estado de coisas e ajudar a todas e todos a formarem suas autonomias, para que desse modo possam situar-se melhor, identificar perigos e apontar aquilo ou aqueles que militam contra o bem-viver. Enquanto instituição social (natureza que deve ser reafirmada e preservada), a universidade é inseparável "da ideia de democracia e democratização do saber: seja para realizar essa ideia seja para opor-se a ela" (Chauí, 2001:185). As instituições universitárias e os centros de excelência na produção de conhecimentos, portanto, não podem "furtar-se à referência à democracia como ideia reguladora, nem pode furtar-se a responder, afirmativa ou negativamente, ao ideal socialista" (Chauí, 2001:185).

O ideal socialista mencionado pela Marilena Chauí pode ser emplacado como programa para governos, ou pura e simplesmente como uma tomada de posição de cada uma e cada um. Slavoj Žižek, ao justificar o subtítulo do seu livro Pandemia: COVID-19 e a reinvenção do comunismo (2020), assevera justamente isso. Não se trata de reduzir o debate ao temor ou à tentativa real de reimplantação de regimes políticos de esquerda, e sim de considerar que as transformações provocadas pelo novo coronavírus sinalizam para a necessidade de mudanças radicais que se aproximam dos ideais do regime a que ele faz menção no subtítulo.

Dito de maneira mais simples, não se sabe que mundo surgirá ou que está sendo gerido a partir de tudo que o planeta, governanças e povos estão vivendo, e ninguém tem como prever o futuro. Entretanto, as demandas que a pandemia impõe andam na contramão dos passos que as sociedades capitalistas trilhavam até então. Admite-se isso e a partir da admissão implementam-se mudanças estruturais radicais, ou a calmaria ainda porvir durará pouco tempo até o sistema entrar em colapso novamente e apresentar novos ciclos pandêmicos arrasadores. 
Sendo assim, é impossível conceber um projeto de tamanha magnitude sem a participação direta e efetiva das universidades e dos produtores de conhecimentos sérios, que serão responsáveis por oferecer às populações os saberes de que precisarão para a reconstrução da vida e do cotidiano interrompidos pela peste que acometeu a espécie humana. Surge desse papel fundamental a necessidade de as instituições universitárias repensarem a si e reelaborarem suas atividades extensionistas a fim de que seus braços e sua perspicácia alcance o centro e os rincões não como exceção, e sim como regra, levando em consideração as discussões levantadas neste artigo.

O objetivo não é outro senão oferecer-se como suporte confiável e despido de prepotências àqueles que, desamparados pelo Estado e presas fáceis dos falsários que habitam e manipulam as $\mathrm{TICs}^{4}$, buscam informações de um modo ou de outro, cada um e cada uma a seu modo, porém, as buscam para entender o que se passa agora e o que se passará depois. Isso fortaleça a experiência democrática e impõe limites aos monopólios de comunicação e medo às plataformas alimentadas pela falsidade dos dados.

Está posto o desafio, o qual não resulta na negação da academia e tampouco na supervalorização dos saberes populares, mas sim na busca por um discurso mais sintonizado com os traços e adversidades do tempo presente, pela intersecção das abordagens de que a cultura humana dispõe, sem que com isso uma seja anulada em privilégio da outra, pois cada sujeito fala de um lugar específico e esse lugar contém histórias, signos de prestígio valiosos, símbolos culturais, significados complexos, racionalidades, contradições e conflitos de interesses que não podem ser negligenciados. Há uma teia de relações mais ampla do que se supõe, por isso, o compromisso passa por encontrar a linguagem adequada para criar pontes, não antipatias incontornáveis entre os saberes.

\begin{abstract}
A ciência moderna legou-nos um conhecimento funcional do mundo que alargou extraordinariamente as nossas perspectivas de sobrevivência. Hoje não se trata tanto de sobreviver como de saber viver. Para isso é necessária outra forma de conhecimento, um conhecimento compreensivo e íntimo que não nos separe e antes nos una pessoalmente ao que estudamos (Santos, 2018b:92).
\end{abstract}

Esse compromisso, antes de pertencer aos que conseguem sobreviver com o senso comum sem repensá-lo, impõe-se aos acadêmicos e formadores de opinião que em princípio detêm um repertório mais diversificado de análise e, por isso, podem apresentar aos alheios outras modalidades de leitura do mundo, de modo que um seja instigado pelo outro e o processo civilizatório das ideias ganhe ainda mais qualidade e, de fato, pensando

\footnotetext{
${ }^{4}$ Tecnologias da Informação e Comunicação.
} 
prudentemente, um maior número de pessoas tenha uma vida decente no sentido de saber como são e funcionam as coisas, a política e os jogos de poder, sobretudo em tempos tão delicados e trágicos.

Cumpre, portanto, pôr em perspectiva as epistemologias e os métodos, as ciências e os saberes formais produzidos pela universidade com vistas a readequar os quadros de referência, alguns critérios e postulados. Ao pôr em perspectiva essas questões, refazer didáticas e práticas educativas em busca de um ensino que seja eficaz, socialmente reconhecido e valorizado nos seus termos.

\section{Considerações finais}

Levadas até as últimas consequências as propostas expostas neste trabalho, pode-se concluir o seguinte: já passou da hora de substituir a noção banal "formadores de opinião" pelo conceito de "formadores de consciências", a fim de que especialistas, estudiosos, pesquisadores, professores e personalidades contribuam efetiva e beneficamente para a construção de um projeto de país, de mundo e de cidadania irrevogáveis, resistentes a assédios das mais variadas ordens e considere o bem-comum como princípio inegociável, de sorte que as ciências sejam, mais do que um exercício intelectual, um exercício politizador de conscientização.

Essa consciência, obviamente, não se constrói de um dia para o outro, posto que é resultado de processos histórico-políticos radicais. Todavia, as rupturas e mudanças incontornáveis provocadas pela pandemia oferecem aos contemporâneos a chance de usar essa horrível tragédia como ponto de inflexão em direção à construção de outros modos de ser, estar e pensar. É o destino das gerações futuras e do próprio planeta que está em jogo.

Os saberes são diversos, os métodos são diferentes, e há tantas maneiras de olhar para o mundo como há narrativas que traduzem esses olhares em palavras. Essa diversidade, no entanto, acontece, choca-se, surpreende-se, torna-se conhecida no mesmo planeta, no mesmo regime político compartilhado por letrados e iletrados. Se os diferentes não dialogarem, a sorte do planeta, da política e dos sujeitos estará em risco.

Falamos "ciência" no singular para designar uma sabedoria genérica e podemos falar no plural, ciências, para expressar a diversidade dos fazeres acadêmicos. O que não se admite pelas discussões entabuladas neste trabalho é que, tanto no singular como no plural, as atitudes sejam excludentes. Portanto, cabe às universidades, aos centros de produção de 
conhecimento, aos intelectuais, aos artistas o engajamento pela democratização dos saberes e pelo respeito àquilo que está fora de seus circuitos.

Há direitos e deveres, responsabilidades e omissões que a História registra. Essas instituições e personas devem questionar e responder como cada um dos agentes envolvidos nessa trama será retratado, lembrando que enquanto se pensa no que fazer ou como fazer e muitos correm atrás de vacinas, tratamentos e soluções, as pessoas continuam morrendo porque lhes faltou a necessária conscientização.

Um mundo novo, por definição, pede novas posturas. Aliás, seu surgimento não acontece do nada: depende exclusivamente do que se fará, ou seja, novas posturas desenham novos mundos. Ao mesmo tempo que a educação no sentido geral do termo e sua capacidade de reinventar-se assume centralidade nessas discussões, reflexões devem ser feitas e horizontes a conquistar e novas atitudes aparecem como metas primordiais. Resta saber se os profissionais envolvidos e interessados na temática estarão dispostos a esse trabalho fundamental e imensamente recompensador. Aos que estiverem dispostos, a inserção e importância social que terão será clarividente.

Pensar e engajar-se na elaboração de formas mais qualificadas de pensamento, abertas aos cientistas e também aos que não se encaixam nessa categoria, para melhorar as condições de vida das pessoas, estabelecer diálogos, acolher saberes, observar movimentos socioantropológicos sem menosprezá-los a priori são deveres que cada formador de consciência solidária, comunitária e cidadã tem para com suas pesquisas e suas incursões no seio da sociedade, sejam elas mediáticas ou não.

A tarefa não é simples, afinal, demanda pôr em perspectiva crítica a epistemologia e os métodos clássicos que fundamentam a formação de cada pesquisador. O objetivo consiste em reelaborar o que se tornou confortável, mas limitado; trocar quadros de referências até então usados como régua para aferir todos fenômenos e ter a grande ética de admitir que seu campo de conhecimento por mais consolidado que seja possui limitações, preconceitos e defeitos que outros saberes revelam.

Esse não é outro senão o dever do cientista. Quem faz ciência não deve se acomodar e manter-se seguro na burocracia dos seus trabalhos que falam apenas para seus pares e têm raríssimos pontos de contato com o grande público, que, na grande maioria dos casos, no Brasil em particular, foi e é quem financia, por meio de seus tributos, o processo formativo de pesquisadores. Como pode-se constatar, essa não é uma temática restrita aos círculos de debate entre especialistas, e sim um assunto que no caso da pandemia do novo coronavírus redunda em vida ou morte. 


\section{Referências}

ALMEIDA, Maria da C; KNOBBE, Margarida Maria (2003), Ciclos e metamorfoses: uma experiência de reforma universitária. $1^{\mathrm{a}}$ ed. Porto Alegre, Sulina.

BECKER, Ernest (2015), A negação da morte: uma abordagem psicológica sobre a finitude humana. $7^{\mathrm{a}}$ ed. Rio de Janeiro, Record.

CHAUÍ, Marilena (2001), Escritos sobre a universidade. $1^{\mathrm{a}}$ ed. São Paulo, Editora UNESP.

CORTELLA, Mário Sérgio (2015), Pensar bem nos faz bem: família, carreira, convivência, ética. $4^{\text {a }}$ Ed. Petrópolis, Vozes.

HAN, Byung-Chul (2018), No enxame: perspectivas digitais. $1^{\mathrm{a}}$ ed. Petrópolis, Vozes.

LOVELUCK, Benjamin (2018), Redes, liberdades e controle: uma genealogia política da internet. Petrópolis, Vozes.

MORIN, Edgar (2011), Os sete saberes necessários à educação do futuro. $2^{\mathrm{a}}$ ed. São Paulo, Cortez.

MORIN, Edgar (2012), O método 5: a humanidade da humanidade. $5^{\mathrm{a}}$ ed. Porto Alegre, Sulina.

MORIN, Edgar (2013), Meus demônios. $6^{a}$ ed. Rio de Janeiro, Bertrand Brasil.

MORIN, Edgar (2015), Introdução ao Pensamento Complexo. $5^{\text {a }}$ ed. Porto Alegre, Sulina.

MORIN, Edgar (2018a), Ciência com consciência. 17 ed. Rio de Janeiro, Bertrand Brasil.

MORIN, Edgar (2018b), A cabeça bem-feita: repensar a reforma, reformar o pensamento. $24^{\mathrm{a}}$ ed. Rio de Janeiro, Bertrand Brasil.

SANTOS, Boaventura de Sousa (2011), A Universidade no século XXI: para uma reforma democrática e emancipatória da Universidade. $3^{\mathrm{a}}$ ed. São Paulo, Cortez.

SANTOS, Boaventura de Sousa (Org.) (2018a), Conhecimento prudente para uma vida decente. $2^{\mathrm{a}}$ Ed. São Paulo, Cortez.

SANTOS, Boaventura de Sousa (2018b), Um discurso sobre as ciências. $8^{\text {a }}$ Ed. São Paulo, Cortez.

STENGERS, Isabelle (2002), A invenção das ciências modernas. $1^{a}$ ed. São Paulo, Editora 34.

ŽIŽEK, Slavoj (2020), Pandemia: COVID-19 e a reinvenção do comunismo. $1^{\mathrm{a}}$ ed. São Paulo, Boitempo. 


\begin{abstract}
This article is based on a qualitative analysis of an exploratory nature, discussing the differences between scientific knowledge, built and consolidated through collectivities and rigorous consensus, and the opinion as a mere expression of individual knowledge whose validity, more often than not, is not subject to analysis and criticism to the point of producing careless actions that put at risk social relations, having as its motto the consequences of the pandemic caused by the new coronavirus. For this reason, fundamentally, the study is based on the theoretical contributions of Complex Thought and proposes changes in the inflexible classic scientific method. Moreover, it demonstrates the place occupied by the university in this debate, besides defining each one of that knowledge and presenting the challenges that the pandemic brought up.
\end{abstract}

Keywords: Pandemic; University; Science; Opinion.

\title{
Resumen
}

Este artículo, basado en un análisis cualitativo de carácter exploratorio, aborda las diferencias entre el conocimiento científico, construido y consolidado a través de colectividades y consensos rigurosos, y la opinión como mera expresión del conocimiento individual cuya validez, en la mayoría de los casos, no está sujeta a análisis y críticas hasta el punto de producir acciones descuidadas que ponen en riesgo las relaciones sociales, teniendo como lema las consecuencias de la pandemia provocada por el nuevo coronavirus. Para ello, fundamentalmente, el estudio se basa en las aportaciones teóricas del Pensamiento Complejo y propone cambios en el inflexible método científico clásico y demuestra el lugar que ocupa la universidad en este debate, además de definir cada uno de esos conocimientos y presentar los retos que ha planteado la pandemia.

Palabras clave: Pandemia; Universidad; Ciencia; Opinión. 